\title{
Subglottic Cancer Pathologic Regional Lymph Nodes TNM Finding v6
}

National Cancer Institute

\section{Source}

National Cancer Institute. Subglottic Cancer Pathologic Regional Lymph Nodes TNM

Finding v6. NCI Thesaurus. Code C64701.

A pathologic finding about one or more characteristics of subglottic cancer, following the rules of the TNM AJCC V6 classification system as they pertain to staging of regional lymph nodes. 